\title{
STUDY OF TENSILE PROPERTIES OF CERTAIN SOUTH INDIAN WOOL AND WOOL POLYESTER BLENDED YARNS
}

\author{
H.M. DEVARAJA ${ }^{1}$, S.SUGUMAR ${ }^{2} \&$ H. R. ARUNKUMAR ${ }^{3}$ \\ ${ }^{1}$ Research Scholar, Govt., S.K.S.J.T. Institute, K.R. Circle, Bangalore, India \\ ${ }^{2}$ Retired Associate Professor, Govt. S.K.S.J.T. Institute, K.R. Circle, Bangalore, India \\ ${ }^{3}$ Managing Director, Karnataka State Coir Co-op Federation Ltd, Rajajinagar, Bangalore, India
}

\begin{abstract}
There are more than 42 Sheep breeds in India. These breeds have generally been named after their place of origin, or on the basis of prominent characteristics. In this research paper, some south Indian Bellary breed sheep and Hassan breed sheep wool are considered. Bellary breeds sheep and Hassan breed sheep wool is courser in nature. The Indian Bellary breed sheep and Hassan breed sheep woolen fibers are used, to produce hand spun yarns. The Bellary breed wool is blended with polyester fibers, to make blended yarn. The regular woolen yarns produced by the local hand spinners are studied. The effect of blend on Bellary breed wool with polyester is also studied. The study shows that, the Bellary breed wool, polyester blended hand spun yarns have high strength and elongation.

KEYWORDS: Bellary Breed Wool, Hassan Breeds Wool, Polyester, Hand Spinning, Uniformity of Yarn, Hairiness, Breaking Strength \& Breaking Elongation
\end{abstract}

Received: Sep 01, 2017; Accepted: Sep 23, 2017; Published: Oct 21, 2017; Paper Id.: IJTFTOCT20175

\section{INTRODUCTION}

Bellary breeds wool, Hassan breeds wool is courser in nature. The woolen yarns produced by hand spinners in some villages of south India, are of $100 \%$ woolen yarns, used to make woolen blankets. Woolen blankets weavers of villages are not earning much profits, because the woolen blankets produced by the weaver are of inferior quality, which cannot be marketable to the other sectors. The blankets are not expected to have durability and having no value addition. Hence, the attempt has been made to produce wool and polyester blended yarn.

\section{Wool Fiber}

Wool is the keratinized protein fiber, extended above the skin. Keratinized fibers are dead tissues. The pigments presents in wool fibers are more common in primitive breeds. Most of the primitive breed's wool is used for carpet wool types. Wool is a Natural, Renewable and sustainable fiber. Due to wool's natural crimp and high bulk, it traps lot of air. Wool is a hydroscopic fiber, and it is able to absorb and desorbs moisture vapor as condition changes, it is breathable fiber. Wool contains high level of nitrogen and sulfur, which are natural fire retardants, so it is difficult to ignite. Wool fibers consist of various Amino acids with various side groups. (W. E. Morton and J.W.S.Hearle.2008). Density of wool fiber is $1.3 \mathrm{~g} / \mathrm{Cm}^{3}$ (Ford J.F 1966). Yarn Uniformity of a yarn is very determined by the average number of fibers in the cross section, the finer the fibers the more uniform is the yarn. Improved yarn uniformity is a desirable characteristic in its own right on the appearance (Spencer Smith 
1947).

Pokharna A.K Explain the sequence of the process of producing the woolen yarn on the woolen spinning system like batching, oiling, carding, condensing, and spinning etc. (Pokharna A.K. 2003) But, in rural areas the spinners do not use any such sophisticated process methods to produce yarns.

Development of cored wool/polyester blends yarns and their evaluation in fabrics (Robert W. Singleton 1980). 64 s $(22 \mu)$ grade top wool and Terylene are used to produce yarns. Yarns produced are tested and evaluated. And from the same yarns knitted fabrics are produced, tested and evaluated and observed 65/35 wool: polyester fabric shown high tearing and bursting strength than the control sample (100\% wool) fabric. Most of the work is done on machine spun yarns and are very finer quality yarns.

\section{MATERIALS AND METHOD}

\section{Materials}

In this Research, Mainly three type materials used are wool fibers, and Polyester fibers. Wool fibers used are of two breed Fibers of Bellary breeds Black color, Mixed Color Bellary breeds wool, Hassan breed white/yellowish wool, and Polyester.

\section{Wool Fibers}

Wool fibers used are of two types of breed fibers.

- Bellary breed fibers: Black color wool fibers and Mixed Color wool fibers

- Hassan breeds white/yellowish wool,

\section{Polyester Fiber}

Polyester fibers are used to blend with wool to produce the wool polyester blended yarn. Specification of polyester fiber: Fiber Diameter-15 Den, Fiber Hallow-20\%, And fiber Length-66 mm, Type: Non silicate, Crimp: 32 crimps for 64 mm, Supplier of Fiber: Alliance fiber Ltd. Density of Polyester fiber is 1.39 g/ Cm3 (Ford J.F 1966).

\section{METHODOLOGY}

Wool fiber is collected from the formers and shepherds which is shear by the scissors. The fibers collected are sorted according to the color of the wool and cleaned manually. The manually sorted and cleaned wool is fed into the Wool opener machine. The wool is opened and cleaned further by the opener machine. The $70 \%$ wool is mixed with $30 \%$ polyester for the wool blended yarn (W2PH). The tuffs of $100 \%$ wool are taken for spinning for produce W1, W2, and W3 yarns. All the tuffs are spun on Charka (Type of hand spinning) for making yarns. Yarns are tested and results are discussed.

\section{Yarn Properties}

\section{Yarn Linear Density}

Linear density is one of the most important properties to measure the quality of a yarn. Linear density of yarn is also called yarn count expressed in Length per unit weight or weight per unit length (ASTM-D-1059-01). A Tex system of yarn counting is commonly used. A Tex denotes unit of linear density equal to the mass in grams 1000 meters of length of 
textile yarns, roving or slivers (Saville. B.P, 1999). Standard test method ASTM-D-1059-01 is used to measure the yarn count.

\section{Yarn Twist}

The force is introduced axially to the fibers or filament stands hold together to make a firm textile strand called twisting. Twist contributes strength to the yarn. When the twist is increases the strength of the yarn increases. There is a point where the strength of the yarn reaches maximum value while increasing twist, further increasing the twist the strength decreases. (Saville. B. P, 1999)

The introduction of level of twist effects on yarn and fabric properties like strength, handle, moisture absorption, durable properties, luster, etc. (Apurba Das and R. Alagiruswamy, 2010). (Mitsuo Matsudaira et al, 2009) Twist is measured by counting the number of turns per unit length of yarn. Standard test method ASTM-D-1423 is used to measure the yarn twist for produced yarns (ASTM-D-1423-08).

\section{Yarn Evenness properties}

Yarn uniformity explains how the linear density of yarn i.e. weight per unit length deviates from the actual linear density required. The deviations from its actual linear densities are considered as irregularities or Faults. There are some induced irregularities like knots; splices are introduced during the yarn manufacturing process. There is another category of irregularities are occurs due to fibers, and by machines like slubs, neps, thick and thin places (Saville. B.P, 1999)

These faults directly affects on the quality of the yarn and Fabrics.

Uster Evenness Tester 5-S400R 5.50 is used to find the yarn evenness. It works on the principle of Capacitance. The yarn to test is passed through the two parallel plates of the capacitors. The values such as U\%, CV\%, Neps, Thick and thin places are continuously measured electronically, by Uster standard test method.

\section{Yarn hairiness}

The protruding fibers appears on the surface of the staple yarn is called hairiness. In most of the cases the yarn hairiness is an undesirable, because it effects on the quality of the fabric, as well as in the fabric wet processing. Yarn hairiness indicates the number of protruding fibers on the surface of the yarn. The Yarn Hairiness Index can be measured in the Uster evenness tester.

Table 1: Types of Hand Spun Yarns Produced

\begin{tabular}{|l|l|c|}
\hline \multicolumn{1}{|c|}{ SI No } & Yarn code & Details of Yarns \\
\hline 1 & W1 & Bellary Breed 100\% Wool (Natural Black) \\
\hline 2 & W2 & Bellary Breed 100\% wool (Natural Black \& White) \\
\hline
\end{tabular}


Table 1: contd.,

\begin{tabular}{|l|l|l|}
\hline 3 & W3 & $\begin{array}{l}\text { Hassan Breed 100\% wool (Natural White) } \\
\text { W3 }\end{array}$ \\
\hline 4 & W2PH & $\begin{array}{l}\text { Bellary Breed 70\% wool, Polyester 30\% } \\
\text { (Black \&White Wool And White Polyester) } \\
\text { We } \\
\text { pH }\end{array}$ \\
\hline
\end{tabular}

\section{RESULTS AND DISCUSSION}

Results and discussions are made for Yarn count, Twist of yarns, Uniformity U\%, thin places, Thick places, Neps hairiness index Yarn breaking strength and elongation.

\section{Yarn count and Twist}

Table 2: Yarn Count and twist

\begin{tabular}{|l|l|c|c|c|c|}
\hline SI No & $\begin{array}{c}\text { Yarn } \\
\text { Code }\end{array}$ & Tex & Cv\% & $\begin{array}{c}\text { Twist per meter } \\
\text { (TPM) }\end{array}$ & CV\% \\
\hline 1 & W1 & 396 & 79 & 224.41 & 117 \\
\hline 2 & W2 & 346 & 37 & 169.29 & 104 \\
\hline 3 & W3 & 316 & 61 & 196.85 & 122 \\
\hline 4 & W2PH & 344 & 176 & 181.10 & 119 \\
\hline
\end{tabular}

The count of the yarns produced range varies from 316 to 396 Tex. The yarn W1 courser, Yarn W3 is finer yarn. W2PH wool, polyester blended yarn has a more Coefficient of variation. Twist in W1 Yarn is slightly higher comparatively than other yarns. W2 yarn having lowest twist. The coefficient of variation in a twist is not much varied for all the yarns. W2 yarn is blended with polyester to make yarn. W2 and W2PH are having almost same Twist.

\section{Evenness properties}

Evenness properties are measured on Uster Tester 5-S400r 5.50, V=50m/Min, T=0.5 Min, U\% Imperfection, Thick Places, Thin Places, and Neps, Imperfections for $1000 \mathrm{Mts}$

\section{Uniformity \%}

Table 3: Uniformity \%

\begin{tabular}{|l|l|c|c|}
\hline Slno & \multicolumn{1}{|c|}{ Code } & Mean U\% & Cv\% \\
\hline 1 & W1 & 23.42 & 29.74 \\
\hline 2 & W2 & 22 & 27.52 \\
\hline 3 & W3 & 19.48 & 24.56 \\
\hline 4 & W2PH & 24.8 & 31.86 \\
\hline
\end{tabular}




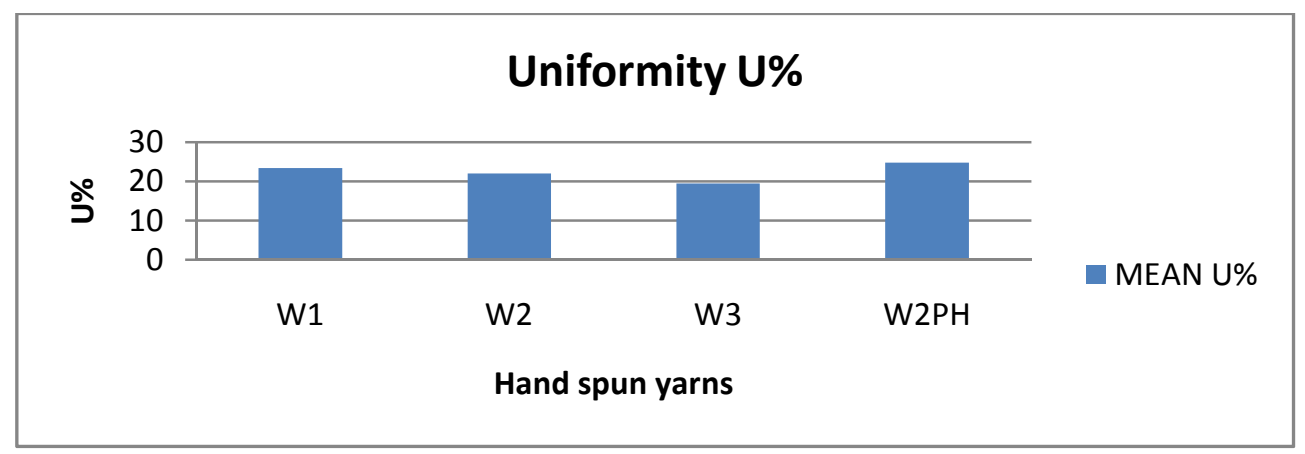

Figure 1: Uniformity U\% of yarns

The W2PH yarn has more Uniformity U\% compare to other yarns. W3 has less variation.

Thin Places, Thick places and Neps

Table 4: Thin Places Thick places and Neps.

\begin{tabular}{|l|l|c|c|c|c|c|c|c|c|c|}
\hline $\begin{array}{c}\text { SLN } \\
\text { O }\end{array}$ & $\begin{array}{c}\text { Yarn } \\
\text { Code }\end{array}$ & $\begin{array}{c}\text { Thin - } \\
\mathbf{3 0 \%}\end{array}$ & $\begin{array}{c}\text { Thin - } \\
\mathbf{5 0 \%}\end{array}$ & $\begin{array}{c}\text { Thin - } \\
\mathbf{6 0 \%}\end{array}$ & $\begin{array}{c}\text { Thick } \\
\mathbf{+ 3 5 \%}\end{array}$ & $\begin{array}{c}\text { Thick } \\
\mathbf{+ 7 0 \%}\end{array}$ & $\begin{array}{c}\text { Thick } \\
\mathbf{+ 1 0 0 \%}\end{array}$ & $\begin{array}{c}\text { Neps } \\
\mathbf{+ 1 4 0 \%}\end{array}$ & $\begin{array}{c}\text { Neps } \\
\mathbf{+ 2 0 0 \%}\end{array}$ & $\begin{array}{c}\text { Neps } \\
\mathbf{+ 4 0 0 \%}\end{array}$ \\
\hline 1 & W1 & 5540 & 1860 & 660 & 3120 & 640 & 160 & 240 & 120 & 20 \\
\hline 2 & W2 & 5720 & 1620 & 460 & 3000 & 340 & 20 & 260 & 60 & 0 \\
\hline 3 & W3 & 6740 & 1300 & 240 & 3020 & 320 & 20 & 220 & 100 & 0 \\
\hline 4 & W2PH & 6080 & 2440 & 1120 & 2980 & 640 & 140 & 260 & 40 & 20 \\
\hline
\end{tabular}

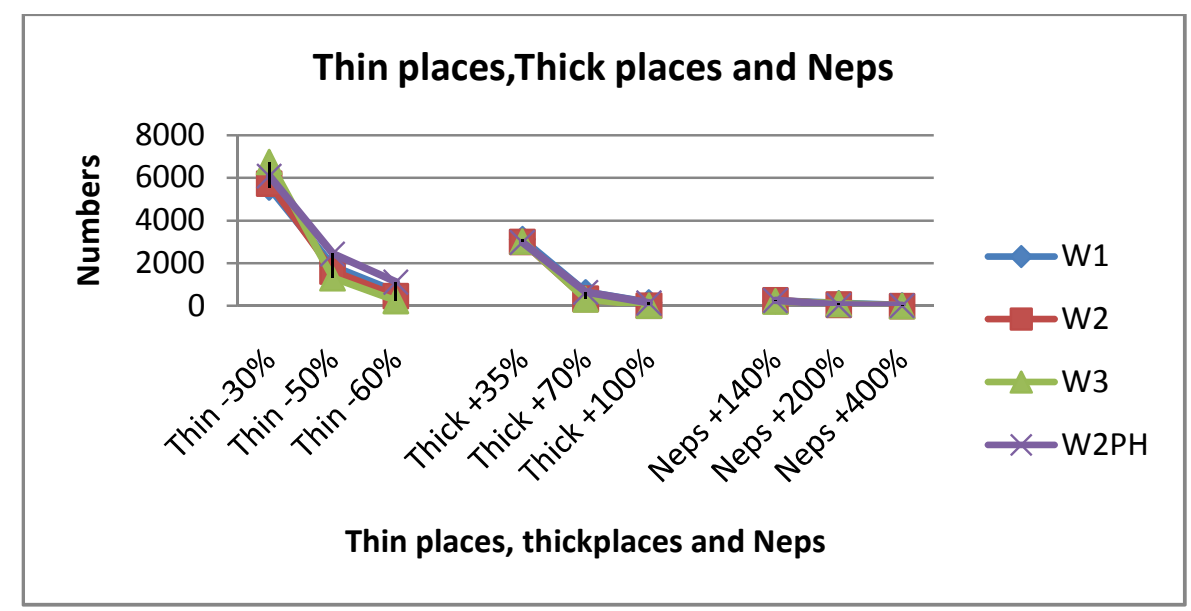

Figure 2: Thin Places, Thick places and Neps.

More number of thin places is occurred in all the yarns compare to thick places and neps. More number of thick places are occurred in all the yarns compare to neps. The numbers of thin places occurred in within $-60 \%$ are less in numbers and within $-30 \%$ thin places has found more thin places. In W2PH yarns thinner places are occurring. More thick places are found in thicknesses of $+30 \%$ thickness sizes in all the yarns. Less thick places are found in thickness of less than $+100 \%$ thickness sizes in all the yarns. Neps are occurred more in all the yarns of $+140 \%$ nep thicknesses, and less in $+140 \%$ of nep thickness.

\section{Hairiness}

To measure the hairiness of the yarn Uster Tester 5-S400r 5.50, - Hairiness Index V=50m/Min, T=0.5 Min, is 
used.

Table 5: Hairiness index

\begin{tabular}{|l|l|c|c|}
\hline Sl no & Code & Hairiness. Index & Cv\% \\
\hline 1 & W1 & 4.47 & 1.93 \\
\hline 2 & W2 & 10.23 & 4.14 \\
\hline 3 & W3 & 15.24 & 5.23 \\
\hline 4 & W2PH & 12.94 & 5.12 \\
\hline
\end{tabular}

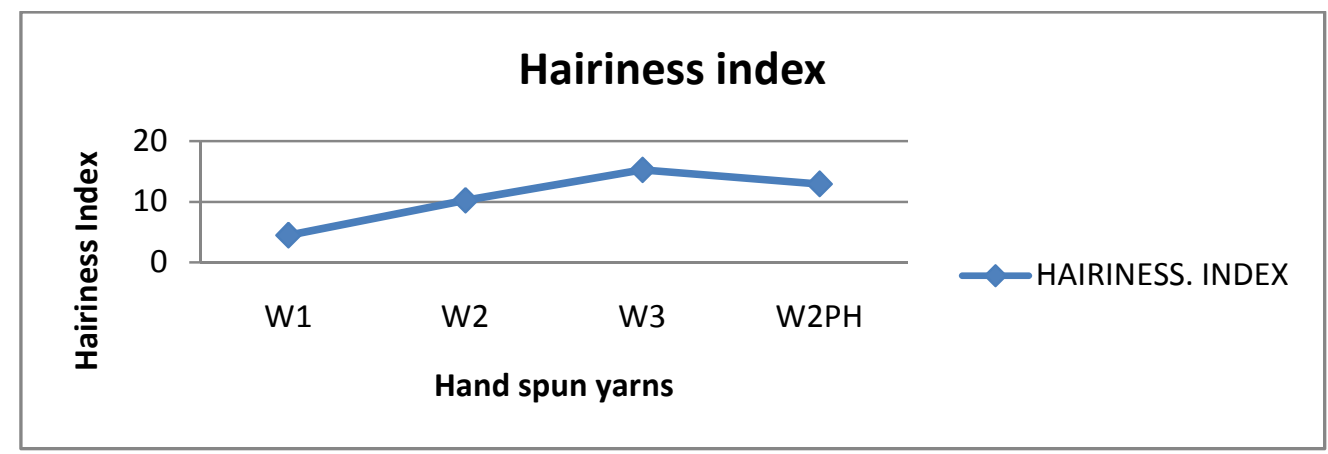

Figure 3: Hairiness index

Hairiness index is more of the W3 yarn, less for W1 yarns. CV\% less for W1 yarn, it means not much variation of hairiness index observed in W1 yarn.

Single Yarn Breaking Force and Elongation \%

Single Yarn Breaking Force and Elongation \% is tested on Instrument: Uster Tenso rapid 3 V7.0, Instrument Setting: V=5000 Mm/Min, as per the Uster standard method.

Table 5: Breaking Strength of the yarns

\begin{tabular}{|l|l|c|c|c|c|}
\hline SLNO & CODE & B-Force (gf) & CV \% of B-force & Rkm (kgf*nm) & B.Work(gf.cm) \\
\hline 1 & W1 & 946.4 & 29.26 & 3.21 & 1707.6 \\
\hline 2 & W2 & 920.1 & 30.13 & 3.12 & 1392.6 \\
\hline 3 & W3 & 751 & 23.99 & 2.54 & 1727.7 \\
\hline 4 & W2PH & 1372.7 & 28.49 & 4.65 & 4570 \\
\hline
\end{tabular}

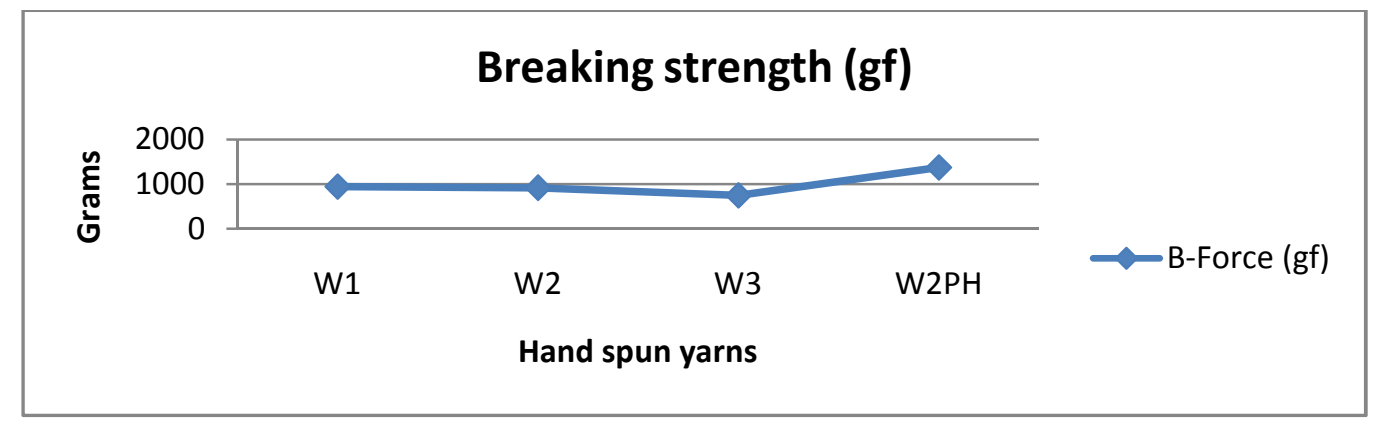

Figure 4: Breaking strength 


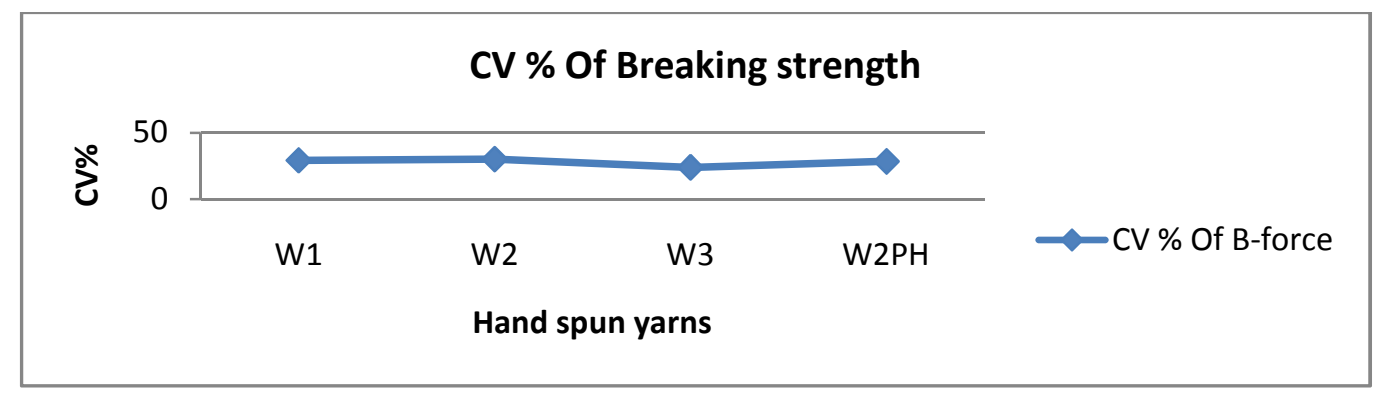

Figure 5: CV\% of Breaking strength

$100 \%$ woolen yarns have less breaking force and Breaking work compare to Polyester and polyester wool blended yarns, it is due to the more content of polyester.

$100 \%$ woolen yarns have taken less time to break the compare to Polyester and polyester wool blended yarns. It is due to the more content of polyester.

Breaking Elongation \%

Table 6: Breaking Elongation

\begin{tabular}{|l|l|c|c|}
\hline SLNO & CODE & $\begin{array}{c}\text { ELONGATION } \\
\text { \% }\end{array}$ & CV\% of Elongation \\
\hline 1 & W1 & 5 & 36.05 \\
\hline 2 & W2 & 4.31 & 31.13 \\
\hline 3 & W3 & 6.08 & 37.84 \\
\hline 4 & W2PH & 8.74 & 39.04 \\
\hline
\end{tabular}

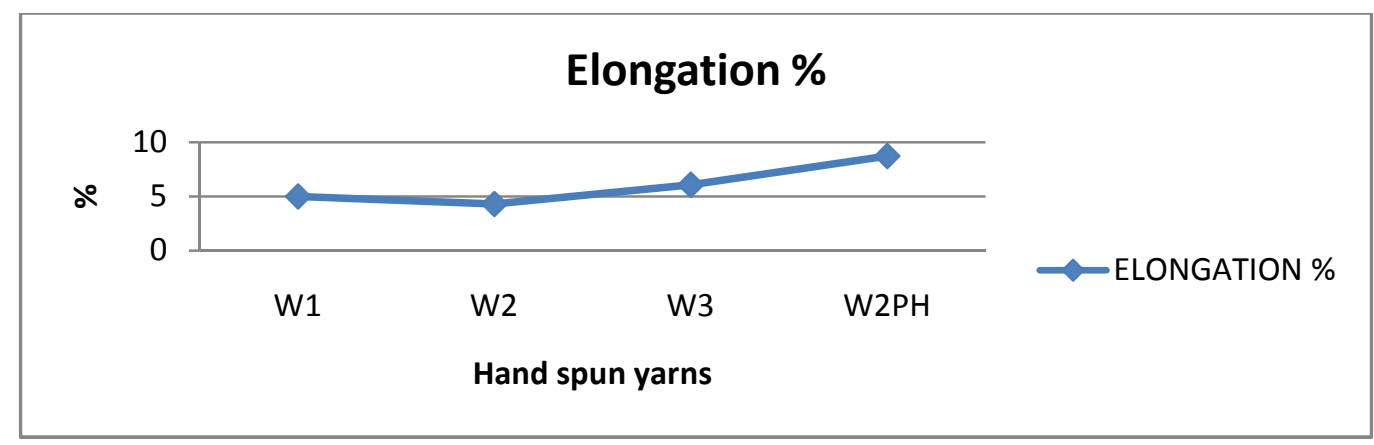

Figure 6: Breaking Elongation

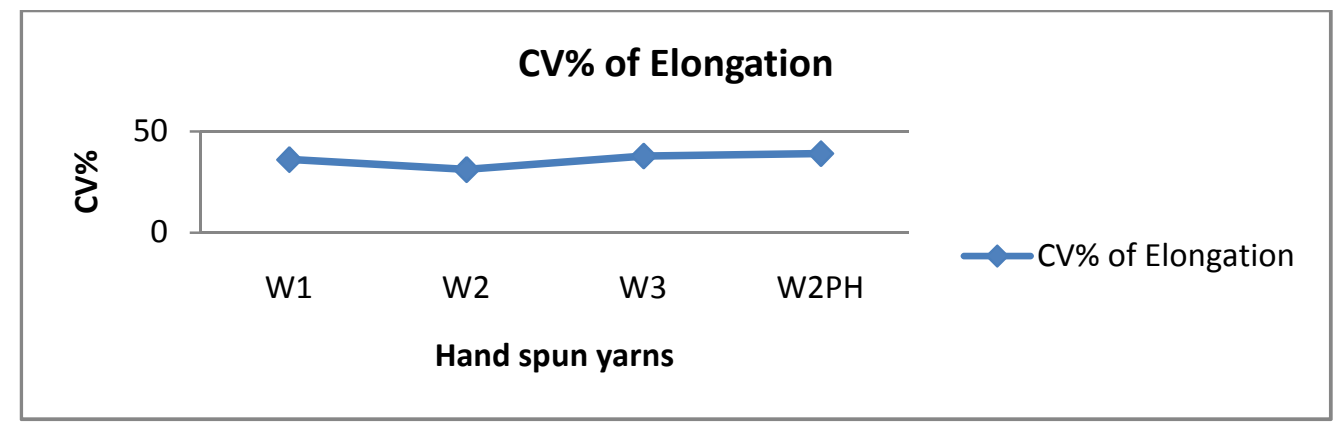

Figure 7: Cv\% of Breaking Elongation 


\section{CONCLUSIONS}

Wool Polyester blended yarn has more breaking force and breaking work, compared to $100 \%$ woolen yarns. It is due to the presence of polyester, in wool polyester. The wool, polyester blended yarn has more elongation $\%$, compared to $100 \%$ woolen yarns. Rural hand spinners can also use different dyed polyester fiber for blending, to get more colored yarns. Rural weavers can produce marketable blankets and can earn profits.

\section{REFERENCES}

1. Apurba Das and R. Alagiruswamy., "Science in clothing comfort" Woodhead publicating India pvt ltd., First edition, 2010.

2. ASTM-D-1059-01: Yarn number based on short-length specimens.

3. ASTM-D-1423-08 Twist in yarns by direct counting.

4. Ford J.F., Fiber data summaries, Shirley Institute, Manchester 1966

5. Mitsuo Matsudaira, K.Nkano, Y.Yamazaki, Yoshiteru Hayashi and Osamu Hayashi “ Effects of weave density, yarn twist, and yarn count on fabric handle of polyester woven fabrics by objective evaluation method" Journal of Textile Institute. Vol.100 No.3,April 2009,pp. 265-274.

6. Manjali Sharma, Suman Pant \& D. B. Shakywar, Cotton and Wool Blends- A Review, International Journal of Textile and Fashion Technology (IJTFT), Volume 5, Issue 4, July - August 2015, pp. 33-42

7. Pokharna A.K., "Processing of wool on woolen spinning system" Winter school report, Central sheep and wool research institute, Sept 2003,

8. $\quad$ Robert W. Singleton Textile Research Journal 1980; 50; 457 (Aug 1980).

9. Saville.B.P. "Physical Testing of Textiles" The Textile Institute, CRC Press, Woodhead publishing India pvt ltd., First edition, 1999.

10. Spencer smith, J.L. Journal Textile institute, 1947, 38, T35.

11. Uster statistics 2007, http://www.uster.com

12. Uster Standard Testing Methods

13. W.E. Morton and J.W.S. Hearle. Physical properties of Textile fibers, $4^{\text {th }}$ edition, wood head publishing in textiles,2008, 